Chapter 11

\title{
Drought in Alpine Areas Under Changing Climate Conditions
}

\author{
Ernst Gebetsroither, Johann Züger and \\ Wolfgang Loibl \\ Additional information is available at the end of the chapter \\ http://dx.doi.org/10.5772/56277
}

\section{Introduction}

Forest ecosystem sensitivity to climate change is a result of direct impacts from climate (e.g. changes of temperature and precipitation) and indirect impacts from several biotic (e.g. pests) and abiotic factors $\left(\mathrm{CO}_{2}\right.$ and Ozone concentration) influenced by climate change [12]. Within this chapter we will concentrate on possible changes for drought hazards due to climate change scenarios. Drought generally has a negative impact on ecosystem productivity and increases mortality. Species adapted to cold and wet conditions with low reproduction rates and limited mobility seem to be most affected. It was found that beech, and surprisingly the broadleaved Mediterranean forests are highly sensitive to drought [1]. The drought of 2003 was in some areas, especially in Germany and France, the strongest drought during the last 50 years. The analysis showed that some time lag effect can occur, thus e.g. for beech the growth reduction was stronger in the following year 2004 after the drought event of 2003. Besides the strong impact of extreme years as 2003 experts assume that in the long run, a change in the frequency of hot and dry years could affect tree species composition and diversity more than one single event [6]. The hydrological cycle at the local scale might superimpose the influences from climate change on a broader scale but extreme events such as droughts cause growth reductions across many site conditions [4]. For the drought analysis within the MANFRED project and because of the information gap ${ }^{1}$ on local site conditions for the whole study area we concentrated our analysis on the predicted input changes from precipitation and temperature.

1 like information about the soil, groundwater, surface runoff etc. 


\section{Method}

\subsection{Regional climate modelling}

Global Circulation Models (GCMs) simulate large scale features of global atmospheric and ocean circulation, based on physical principles. A relevant disadvantage is the coarse horizontal resolution of app. $100-120 \mathrm{~km}$ in mid-latitudes. This resolution is inadequate to reflect the orographic influences and effects of land cover and soil on atmospheric and hydrological processes at regional scales (Figure 1). Therefore a Regional Climate model (RCM) is embedded into a global model to calculate the atmospheric and hydrological processes on finer scales down to $10 \times 10 \mathrm{~km}$ (Figure 2). Along borders the RCM is supplied with data from the GCM, inside the model domain the RCM develops its own dynamics. While the GCM simulates the response of the climate system to global driving forces (greenhouse gas, solar activity, volcanoes ...) the RCM simulates additionally the impact of regional factors like terrain, soil and land cover.

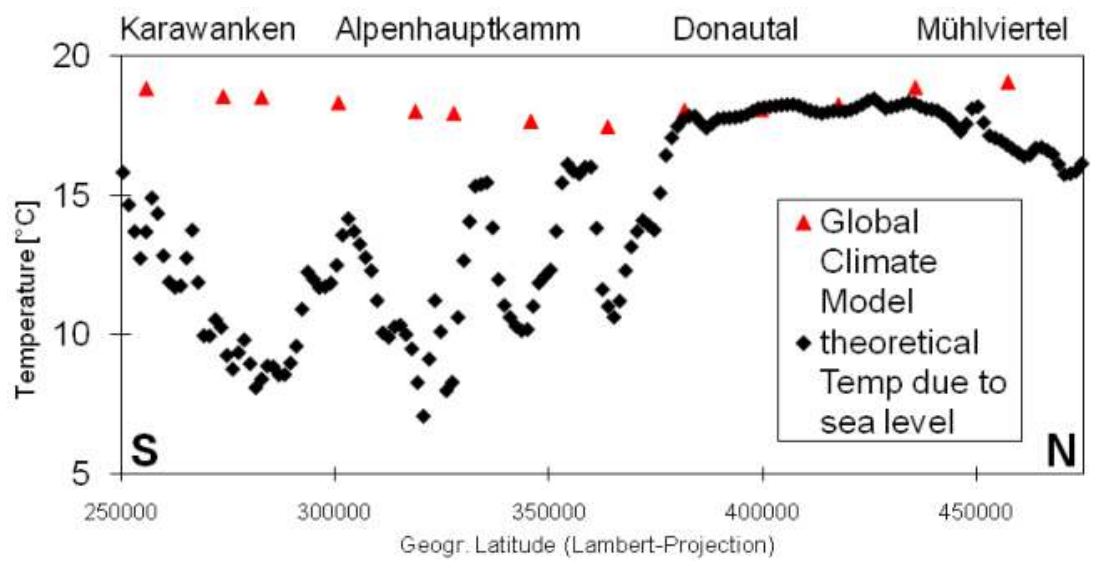

Figure 1. Temperature values in a N-S cross section through the Alps as calculated by GCMs (red triangles) and as expected due to elevation (black squares) ( AIT, figure based on ECHAM4 results and a temperature-elevation gradient based on observation data)

Another important point is to distinguish between weather prediction models and climate models. A weather prediction model starts from actual state of the atmosphere and calculates a few days into the future, but after 10-14 days the model is no longer correlated to the real state of the atmosphere. On the other hand the simulation time in climate models may be up to centuries. Therefore climate models do not describe actual weather, but a potential realisation of weather conditions. Only in long term statistics like mean values or variability a climate model should be similar to real weather behaviour. Weather prediction like: „It's raining on April, $24^{\text {th }} 2045^{\text {“ }}$ is not possible, but statistical information similar to: „The probability of precipitation in June in the 2040s is higher than today" can be derived. 


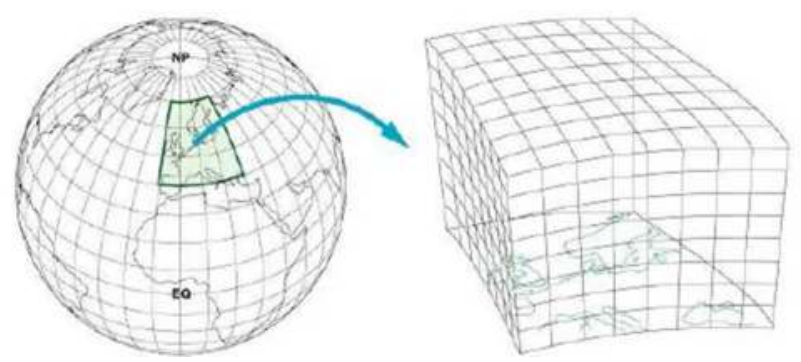

Figure 2. $R C M$ domain $(\Delta x=10-50 \mathrm{~km}$ ) embedded into a GCM ( $\Delta x=100-300 \mathrm{~km})$, Wegener Center Univ.Graz)

\subsection{Three steps to regional climate scenarios}

Regional climate is influenced by global atmospheric conditions and the global climate processes. Hence, for calculations of regional climate scenarios it is necessary to use a stepwise approach, consisting of three main steps:

Step 1: Selection of a particular emission scenario for consideration of atmospheric changes.

Step 2: Selection of a global climate model to calculate the scenarios for global climate processes.

Step 3: Selection of an appropriate regional climate model and calculation of the regional climate scenarios.

\subsubsection{Step 1: Selection of a particular emission scenario for consideration of atmospheric changes}

The Intergovernmental Panel on Climate Change (IPCC) provides a wide range of Green House Gas scenarios based on assumptions of the future development of technologies and society (Figure 3).

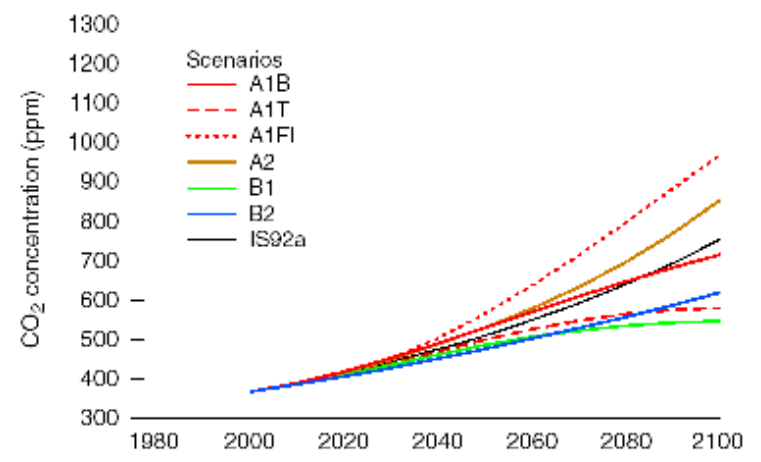

Figure 3. $\mathrm{CO}_{2}$ concentrations in the atmosphere as predicted by different IPCC scenarios (IPCC $3^{\text {rd }}$ Assessment Report Climate Change, 2001²) 
The selection of an appropriate scenario is the first important step towards the estimation of climate change signals. The A1 storyline for example describes a future world of very rapid economic growth, global population that peaks in mid-century and declines thereafter, and assumes rapid introduction of new and more efficient technologies. Major underlying themes are convergence among regions, capacity building, and increased cultural and social interactions, with a substantial reduction in regional differences in per capita income. The A1 scenario family can be divided into three branches describing alternative directions of technological change in the energy system. They are distinguished by their technological emphasis: fossil intensive (A1FI), non-fossil energy sources (A1T), or a balance across all sources $(\mathrm{A} 1 \mathrm{~B})^{3}$. Out of this the scenario $\mathrm{A} 1 \mathrm{~B}$ was selected because it represents a moderate increase of Green House Gases (GHG) and is located in the centre of all covered assumptions (Figure 4). The predicted temperature boost for different emission scenarios additionally depends on the used GCM and covers a range from app. $1^{\circ} \mathrm{C}$ to more than $5^{\circ} \mathrm{C}$. The estimated global temperature increase for the scenario $\mathrm{A} 1 \mathrm{~B}$ until the end of the century is in the range of $+1.5^{\circ} \mathrm{C}$ to $+2.5^{\circ} \mathrm{C}$, which underlines its conservative position as it does not tend to any extreme at the upper or lower bounds.

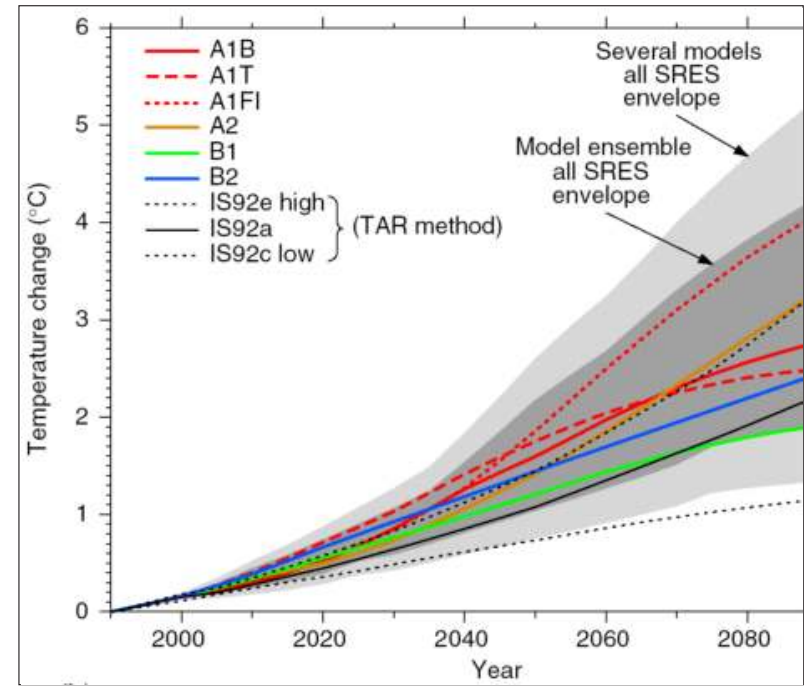

Figure 4. Increase of the global temperature according to different IPCC scenarios ${ }^{4}$, (IPCC, 2001, $3^{\text {rd }}$ Assessment report)

\footnotetext{
2 http://www.grida.no/publications/other/ipcc\%5Ftar/?src=/climate/ipcc_tar/wg1/figspm-5.htm, accessed 15.10.2012 3 http://www.ipcc.ch/pdf/special-reports/spm/sres-en.pdf , IPCC SPECIAL REPORT, EMISSIONS SCENARIOS, 2000 4 http://www.grida.no/publications/other/ipcc\%5Ftar/?src=/climate/ipcc_tar/wg1/fig9-14.htm, accessed 15.10.2012
} 


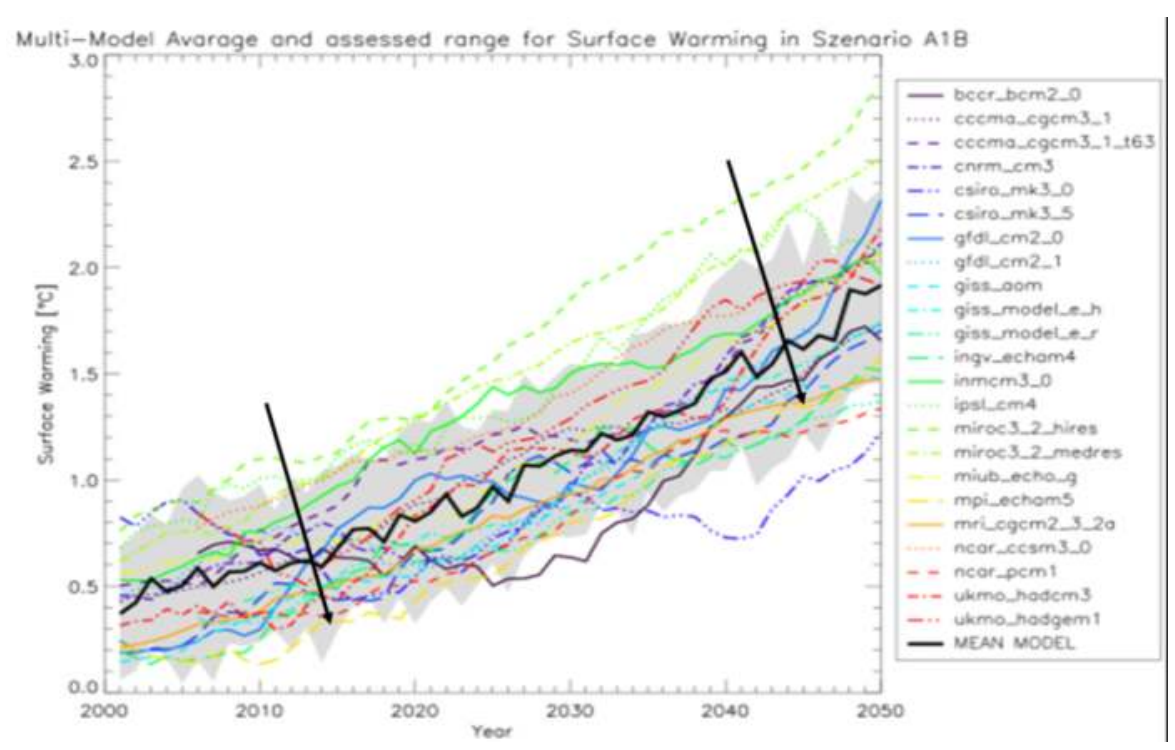

Figure 5. Increase of the global temperature according to the IPCC scenario A1B predicted by different GCMs. The arrows mark the temperature timeline given by the ECHAM5 model (dashed yellow line), [15]

\subsubsection{Step 2: Selection of a global climate model to calculate the scenarios for global climate processes}

The $2^{\text {nd }}$ step in the approach is the choice of the GCM providing the driving data. In our case results from the German ECHAM5/MPI-OM ([17], [18]) model have been used. The temperature increase towards the end of the century predicted by the ECHAM5 model tends to be at the lower end compared to other models (black arrows in Figure 5). Further information on the ECHAM5 model can be obtained from http://www.mpimet.mpg.de/en/wissenschaft/ modelle.html ${ }^{5}$.

\subsubsection{Step 3: Selection of an appropriate regional climate model}

The $3^{\text {rd }}$ step includes the appropriate choice of the RCM providing high resolution data needed for regional analyses. In our case the German "Consortial Runs" [8] were chosen. They were carried out with the RCM Cosmo-CLM ${ }^{6}$. The Grid on which these model runs are based consists of $257 \times 271$ cells with a resolution of $0.165^{\circ}$ which corresponds to app. $18 \times 18 \mathrm{~km}$ in mid-latitudes (Figure 6). The time range of these simulations starts in 1961 and covers 140 years up to 2100. Many atmospheric parameters (like temperature, precipitation, snow, wind components, radiation, cloud cover, etc.) are available on a daily or even hourly basis from the German Climate Data Center (DKRZ) via the Climate and Environmental Retrieval and Archive $\left(\mathrm{CERA}^{7}\right)$. 


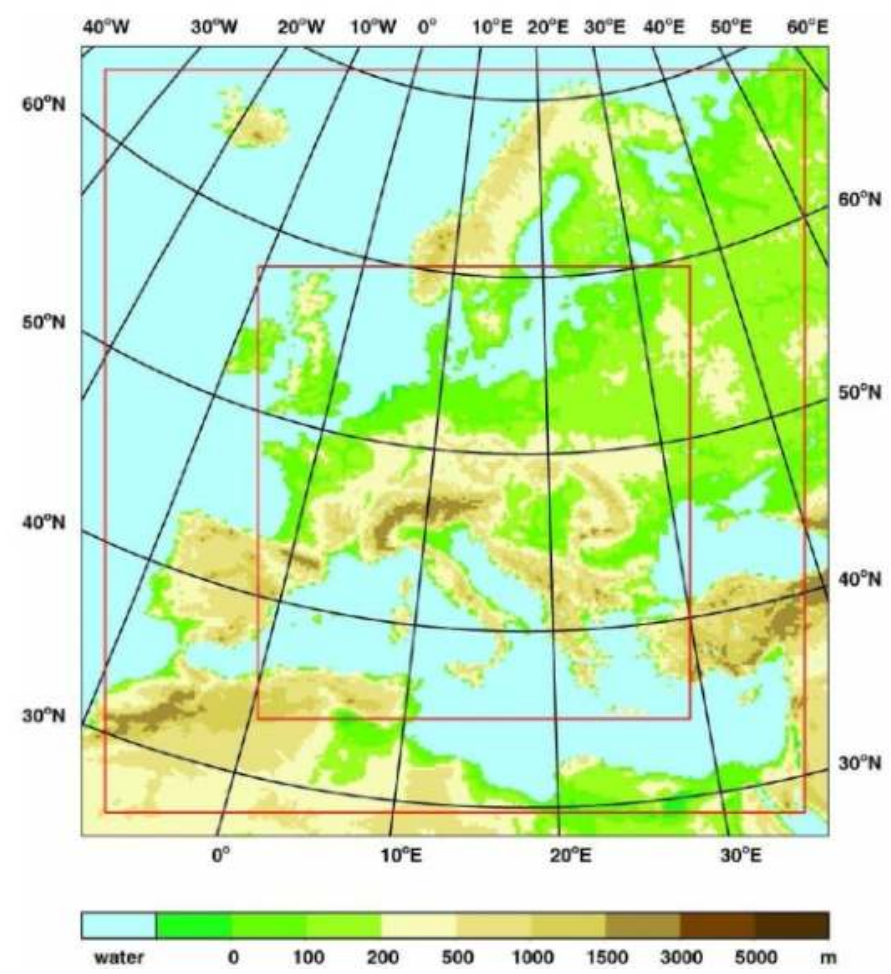

Figure 6. Model domain for Cosmo-CLM Consortial Runs (257x271 cells, resolution: 0,165²), [8]

\subsection{Drought hazard calculation with regional climate input data}

As there is no single drought parameter which can summarize the impact of climate change on drought for forests, it has been decided to calculate several parameters to provide as much information for forest practitioners as possible. For the current study results of the IPCC climate scenario $\mathrm{A}^{8} \mathrm{~B}^{8}$ downscaled to a spatial resolution of $1 \times 1 \mathrm{~km}$ and daily time resolution have been applied. Temperature as well as precipitation data for every day have been analysed within the time period from 1961 to 2100 . As the scenario A1B is rather moderate concerning emissions and temperature increase (cf. Figure $4 \& 5$ ) the results according to climate change impacts on drought presented within the MANFRED project can be seen, despite of the uncertainty of the climate change scenarios, as a quite probable development.

6 http://www.clm-community.eu/, accessed 3.9.2012

7 http://cera-www.dkrz.de,accessed3.9.2012

8 http://www.ipcc.ch/ipccreports/tar/wg1/029.htm (accessed 3.9.2012) and Figure 3\&4 
All calculations have been performed for the whole study area of the MANFRED project with a horizontal resolution of $1 \times 1 \mathrm{~km}$. Climate data where statistically downscaled from the original $18 \times 18 \mathrm{~km}$ simulation results and investigated for 10 case study regions. The downscaling exercise has been conducted by the Swiss Federal Institute for Forest, Snow and Landscape Research (WSL) ${ }^{9}$ (see therefore the particular chapter in this book).

The following list shows the main parameters, which have been calculated as 30-year means:

- Total precipitation during different periods ${ }^{10}$

- Change of total precipitation during different periods

- Mean yearly cycles of daily precipitation

- Mean number of dry days ${ }^{11}$ during different periods

- Mean change of number of dry days during different periods

- Number of dry episodes of different lengths

- Change of number of dry episodes

- Maximum length of dry episodes and changes in the future

- Mean heat wave lengths ${ }^{12}$ during different periods

- Mean change of heat wave lengths during different periods

- Mean daily temperature

\section{Results for the entire Greater Alpine Region (GAR)}

The Figures 7 and 8 show that precipitation in general is reduced in the whole area at any time. For regions south of the Alps a stronger reduction is estimated and the decrease after 2050 is more significant than till 2050.

To calculate the number of dry days we have used a value used a threshold of $1 \mathrm{~mm}$ precipitation per day as threshold for a dry day. This was done because $1 \mathrm{~mm}$ of rainfall usually will not reach the soil in forested areas because it is intercepted in the canopy. Furthermore, climate models tend to overestimate the precipitation and values of zero precipitation occur almost never. The calculation of the number of dry days can be performed with different thresholds, but this will not significantly change the results as we focus on the change signals ${ }^{13}$ and not the absolute values of dry days (Figures 9 and 10).

\footnotetext{
9 http://www.wsl.ch/

10 vegetation period (April to September), annual and seasonal results

11 a dry day is a day with less than $1 \mathrm{~mm}$ precipitation

12 heat waves are: 3 consecutive days with Temp. $>30^{\circ} \mathrm{C} \&$ until mean max. Temp. $<30^{\circ} \mathrm{C} \&$ not max. Temp. of one day $<25^{\circ} \mathrm{C}$
} 


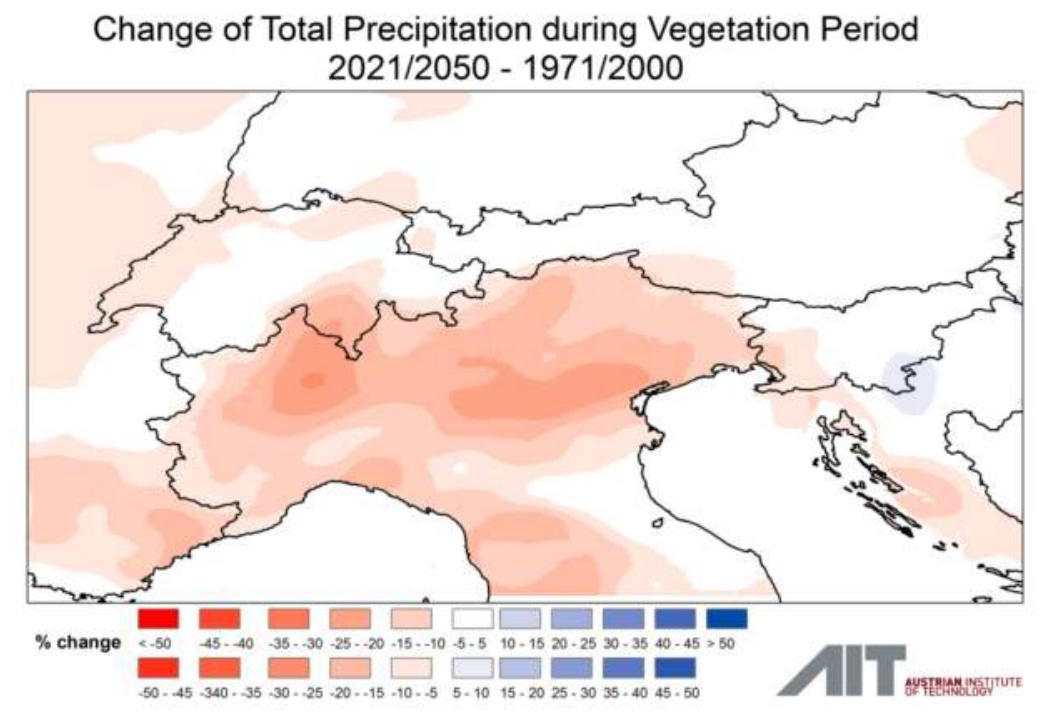

Figure 7. Relative change of total precipitation between 1971/2000 and 2021/2050 (30 yr mean) (Source: ECHAM5/CLM A1B Consortial run, 18x18km resolution, $1 \times 1 \mathrm{~km}$ downscaling: WSL. Data compilation and spatial analysis: AIT)

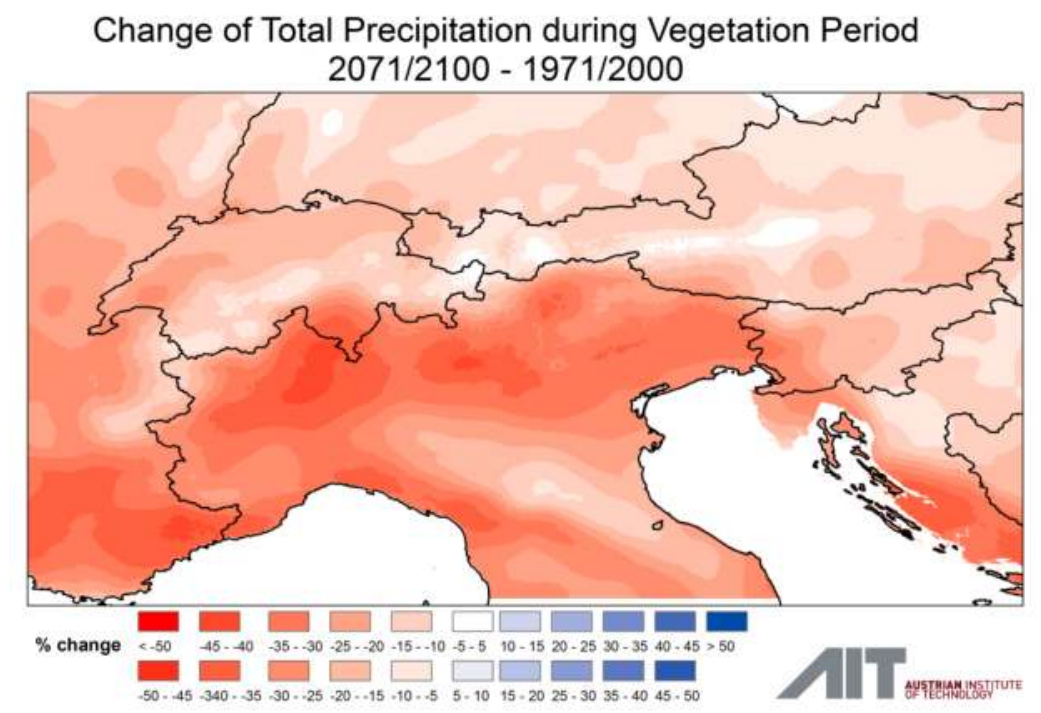

Figure 8. Relative change of total precipitation between 1971/2000 and 2071/2100 (Source: ECHAM5/CLM A1B Consortial run, $18 \times 18 \mathrm{~km}$ resolution, $1 \times 1 \mathrm{~km}$ downscaling: WSL. Data compilation and spatial analysis: AIT)

13 the relative differences not the absolute values 


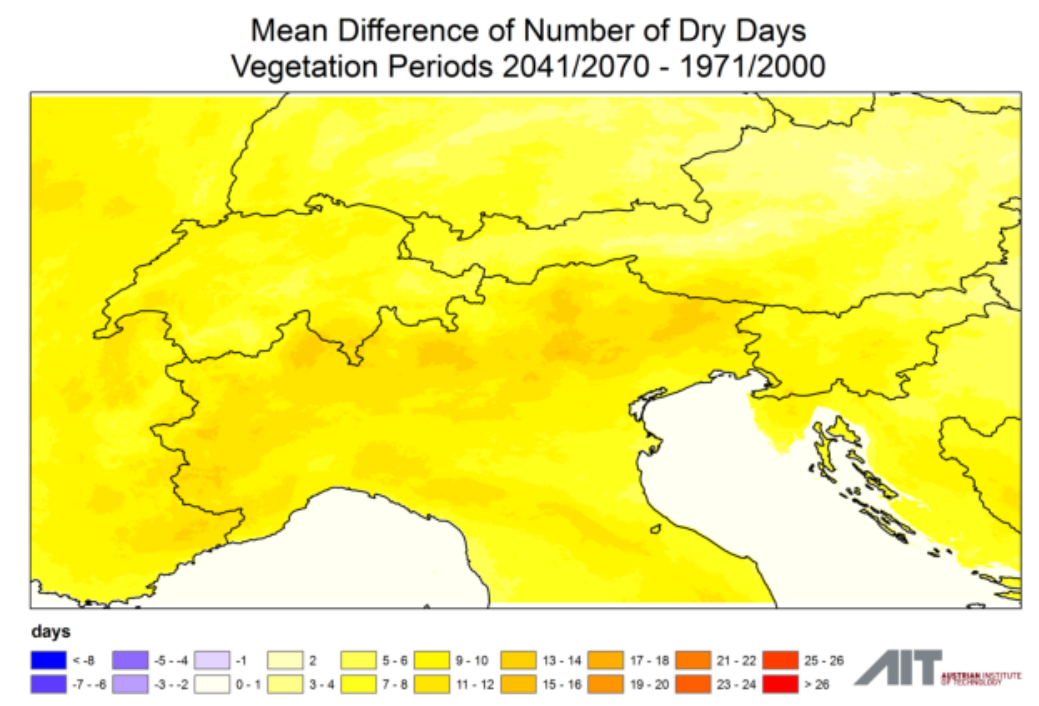

Figure 9. Change of number of dry days during vegetation period in 2041/2070 compared to 1971/2000 (Source: ECHAM5/CLM A1B Consortial run, 18x18km resolution, 1×1 km downscaling: WSL. Data compilation and spatial analysis: AIT)

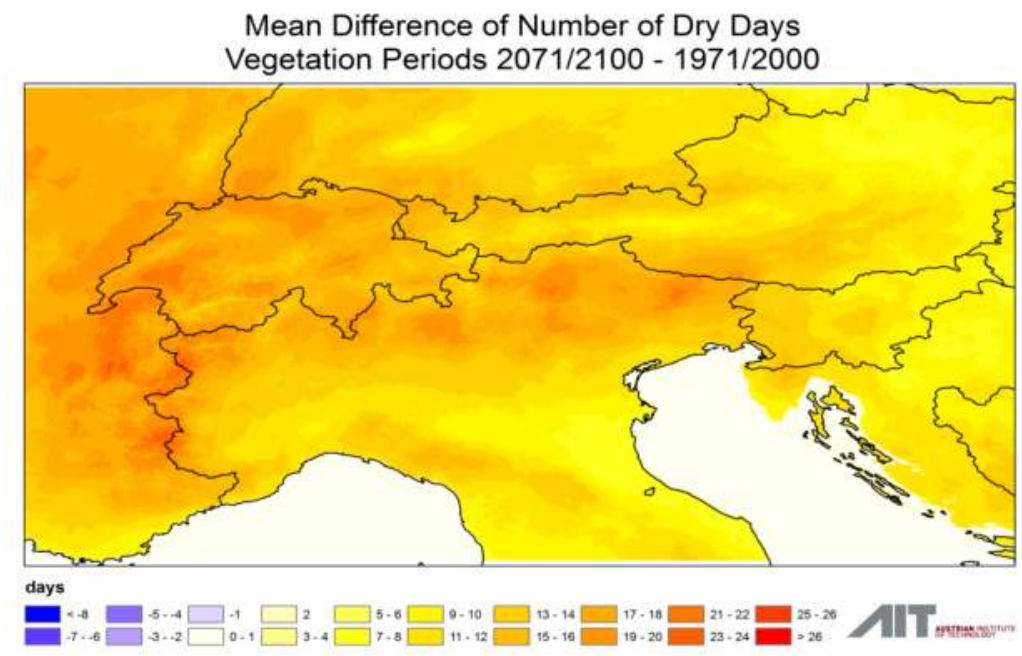

Figure 10. Change of number of dry days during vegetation period in 2071/2100 compared to 1971/2000 (Source: ECHAM5/CLM A1B Consortial run, 18x18km resolution, $1 \times 1 \mathrm{~km}$ downscaling: WSL. Data compilation and spatial analysis: AIT) 
The amount of total precipitation will be reduced in the future, and the number of dry days and also the maximum length of dry episodes will increase. But also the distribution of rainfall during the year will change which may be assumed to have a stronger impact on vegetation (Figure 11).

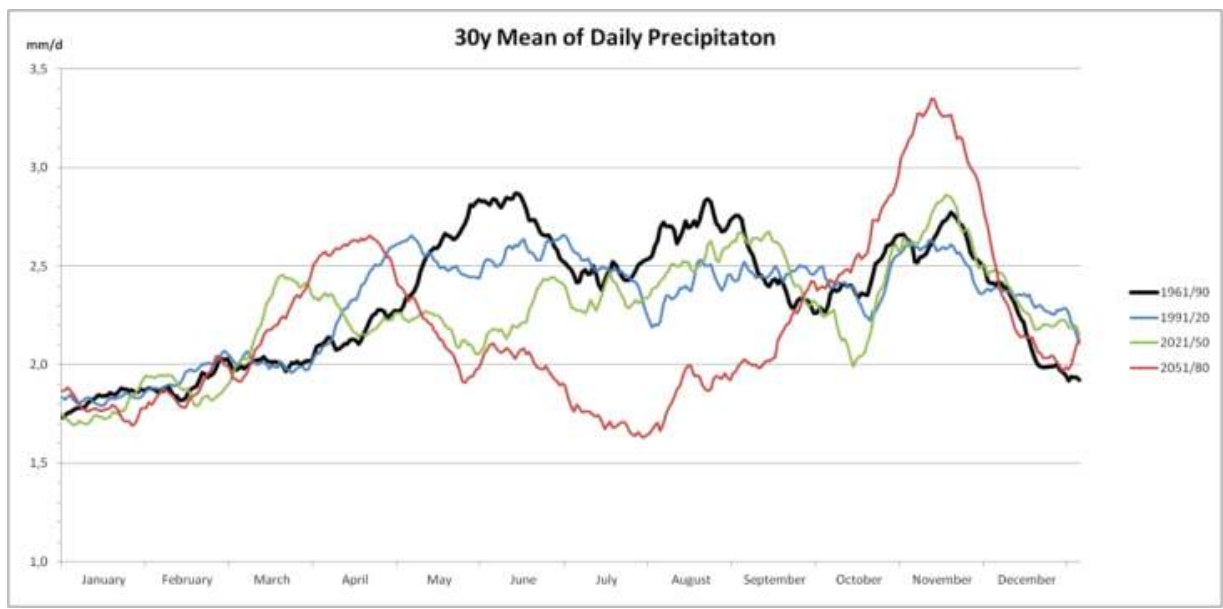

Figure 11. Mean annual cycle of daily precipitation for different periods (30 yr means). (Source: ECHAM5/CLM A1B Consortial run, $18 \times 18 \mathrm{~km}$ resolution, $1 \times 1 \mathrm{~km}$ downscaling: WSL. Data compilation and analysis AIT)

The 30y mean of daily precipitation behaviour for the entire GAR shows a shift from main precipitation during the period from May to August to a maximum in April and November. Major reductions may occur from May to end of September so that during summer the drought hazard will increase significantly and also be strengthened due to the temperature increase in this period of the year, as predicted for the future.

\subsection{Development of heat waves}

As additional parameter we calculated a Heat Wave Index (HWI) according to [7] and [9], which is defined as at least 3 consecutive days with max. temperature above $30^{\circ} \mathrm{C}$ and each further day with max. temperature above $25^{\circ} \mathrm{C}$ as long as the mean of the max. temperatures over the whole period is not below $30^{\circ} \mathrm{C}$. Usually, temperature decreases with higher altitudes, which means that a threshold of $30^{\circ} \mathrm{C}$ will never be reached in these regions. Nevertheless, some "heat waves" will also occur at higher elevations. To be able to calculate a HWI in a mountainous region, all temperature values had to be normalized to sea level. To achieve this, an average temperature gradient of $0.7^{\circ} \mathrm{C}$ for each $100 \mathrm{~m}$ of altitude was assumed. Thus, from a Digital Elevation Model (DEM) of the Greater Alpine Region with a spatial resolution of $1 \mathrm{~km}$ a theoretical temperature at sea level was calculated. These normalized temperature values were used to determine the HWI for the vegetation period from April to September (Figure 
12 and 13). As shown in Figure 14 the maximum length of heat waves increases over the entire GAR, with significant stronger rise south of the Alps.

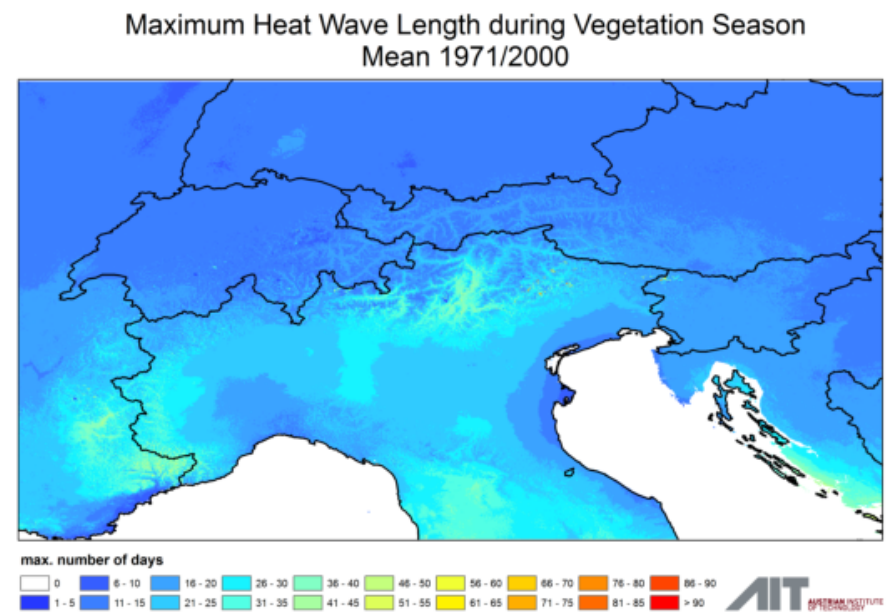

Figure 12. 30-year mean of maximum heat wave length during vergetation period vegetation season 1971/2000 temperature normalized to sea level. (Source: ECHAM5/CLM A1B Consortial run, 18x18km resolution, 1x1km downscaling: WSL. Data compilation and analysis: AIT)

Maximum Heat Wave Length during Vegetation Season Mean $2071 / 2100$

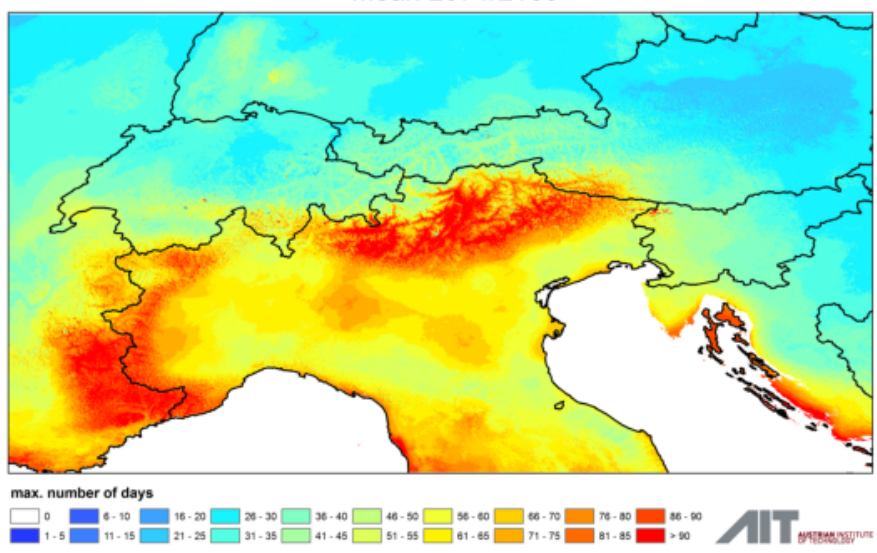

Figure 13. 30-year mean of maximum heat wave length during vergetation period vegetation season $2071 / 2100-$ temperature normalized to sea level. (Source: ECHAM5/CLM A1B Consortial run, 18x18km resolution, 1x1km downscaling: WSL. Data compilation and analysis: AIT) 


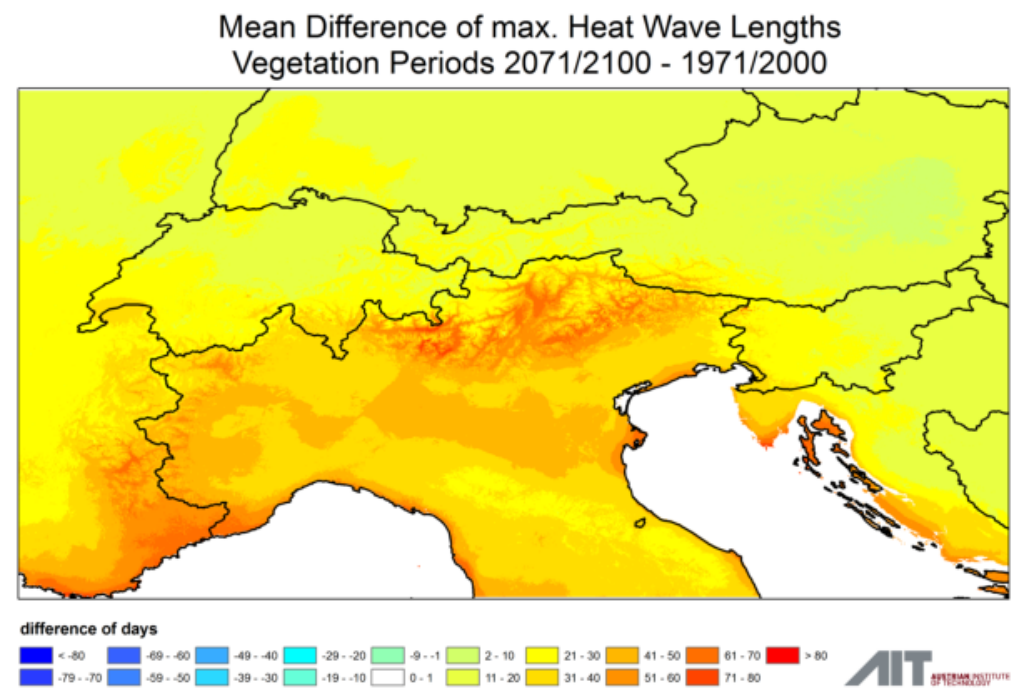

Figure 14. Change of maximum heat wave length during vergetation period for $2071 / 2100$ compared to $1971 / 2000$ - temperature normalized to seal level (Source: ECHAM5/CLM A1B Consortial run, 18x18km resolution, 1x1km downscaling: WSL. Data compilation and analysis: AIT)

\section{Presentation of major results for the case study regions}

This section discusses exemplarily major results for five of the ten case study regions. The different location of the regions can be seen in Figure 15. Location and extent of the regions have been provided by the project partners of MANFRED. The criteria for taking the five samples out of the ten was to select one from each country providing sample regions as well as covering the climate characteristics from north to south and from west to east.

All results represent statistical means of the entire regions of interest. Larger regions - overall the Italian region I1 (Lombardy) - show a wider range of climate characteristics as the area reaches from low elevated areas with Mediterranean influence to high Alpine areas. The differences in the area mean and area max values give some hint regarding the range of the values.

The following table of diagrams (Figure 16) presents the annual variation of precipitation for the selected case study regions. They all show declining precipitation during the summer months. But from north to south the changes somehow deviate. In the northern regions influenced by Atlantic climate ("Nordstaulagen") - the case study regions D1, A1 may expect a growing peak of spring precipitation and from May to September a high decrease during the future decades. The regions, which are influenced by the Mediterranean Sea (I1 and S1) will face a decline of summer precipitation and the evolution of two distinct peaks: a smaller spring 


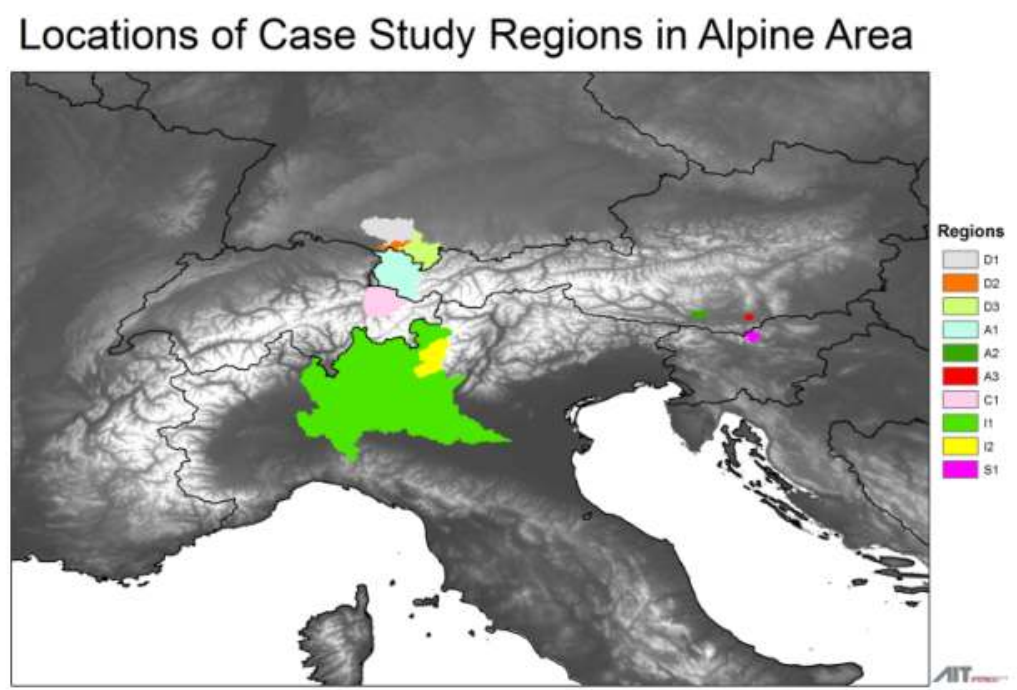

Figure 15. Location of the ten case study regions explored in MANFRED

peak and a high peak in November. The Swiss region (C1) seems to be affected by both influences - the precipitation decline in summer is still high, two precipitation peaks occur a higher spring peak which is characteristic for the northern regions and a smaller autumn peak which is typical for Mediterranean influence. In all areas there is a significant secondary sink in October.

The diagrams in Figure 17 show the evolution of the total precipitation during the growing season for the selected case study regions: All regions show a moderate decline of the average and the maximum rainfall sum. The German (D1) as well as the Slovenian (S1) case study region show moderate precipitation ranges between 600 and $800 \mathrm{~mm}$ which declines in Germany to 600 for max values and $550 \mathrm{~mm}$ for average values, in Slovenia the max values remain almost the same, the average values decline from almost $700 \mathrm{~mm}$ to $350 \mathrm{~mm}$. All other case study regions show an absolute decline of about $100-200 \mathrm{~mm}$ of the max values in the high alpine areas and again an absolute decline of about $50-100 \mathrm{~mm}$ of the average numbers referring more to the low elevated areas. For the lower elevated areas like the Italian region I1 the decline may turn out to be severe as the precipitation sum during the vegetation period is between 500 and $700 \mathrm{~mm}$ and the temperature is going to be higher which results in higher evapotranspiration.

While in Figure 17 the total precipitation during the growing season is shown, Figure 18 depicts the seasonal precipitation sums during different 30 year periods. In all regions a significant decrease of the summer precipitation is obvious: the total rainfall during summer declines from 400 to $300 \mathrm{~mm}$ in the northern regions, from app. 400 to $250 \mathrm{~mm}$ in the Slovenian region (S1) and from 250 to $150 \mathrm{~mm}$ in the Italian areas with Mediterranean influences (I1). 

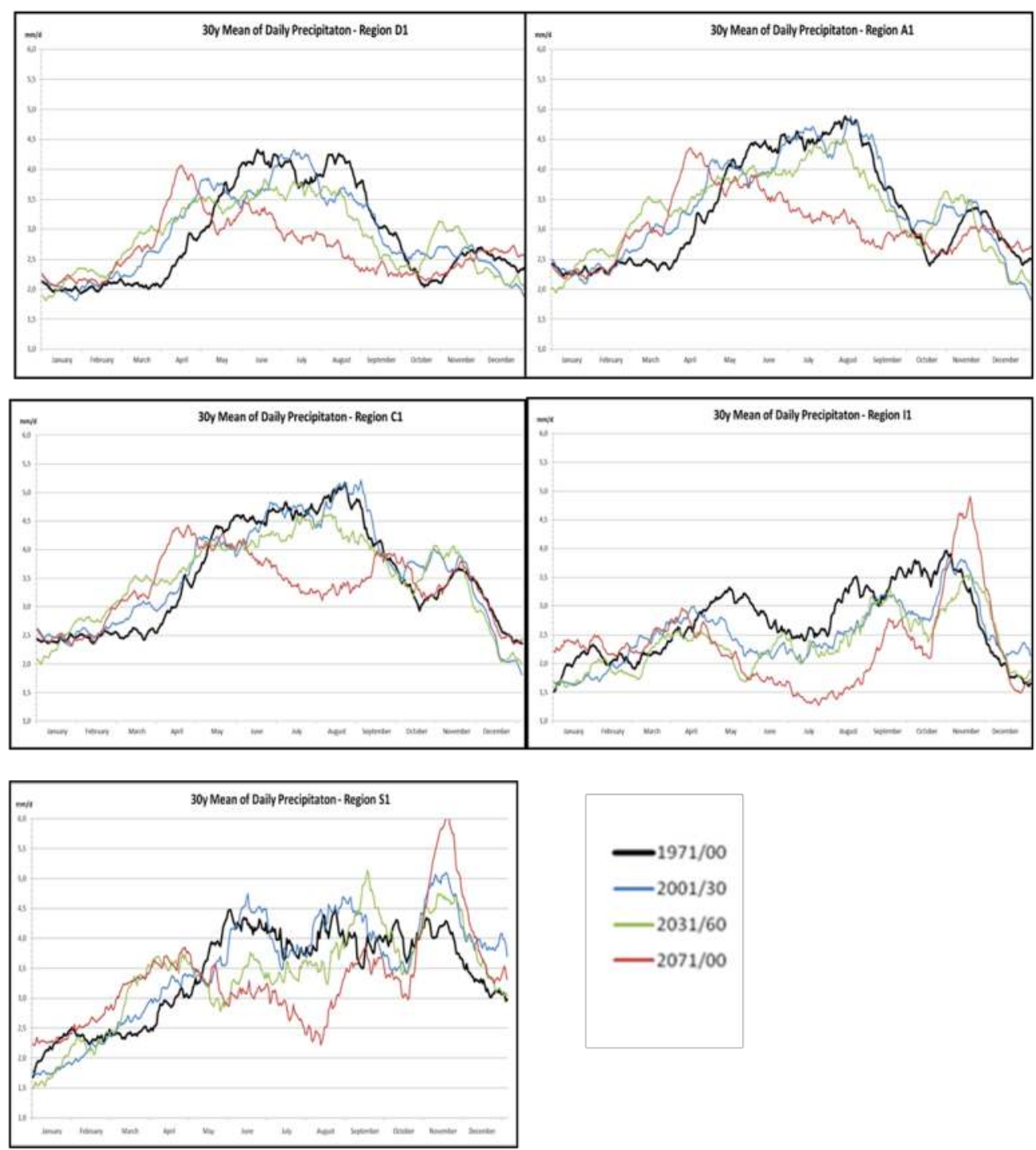

Figure 16. Mean yearly distribution of precipitation from 1971/2000 to 2071/2100 for case study regions D1, A1, C1, 11 and S1 (Source: ECHAM5/CLM A1B Consortial run, 18x18km resolution, 1x1 km downscaling: WSL. Data compilation and analysis: AIT)

The following table of diagrams (fig. 19) indicates the evolution of the number of dry days during the vegetation season for the selected case study regions. All regions show a distinct increase of the average and the maximum number of dry days: the less alpine German region (D1) starting from 69 (average) / 73 (max) dry days may expect an extra of about 20 dry days 

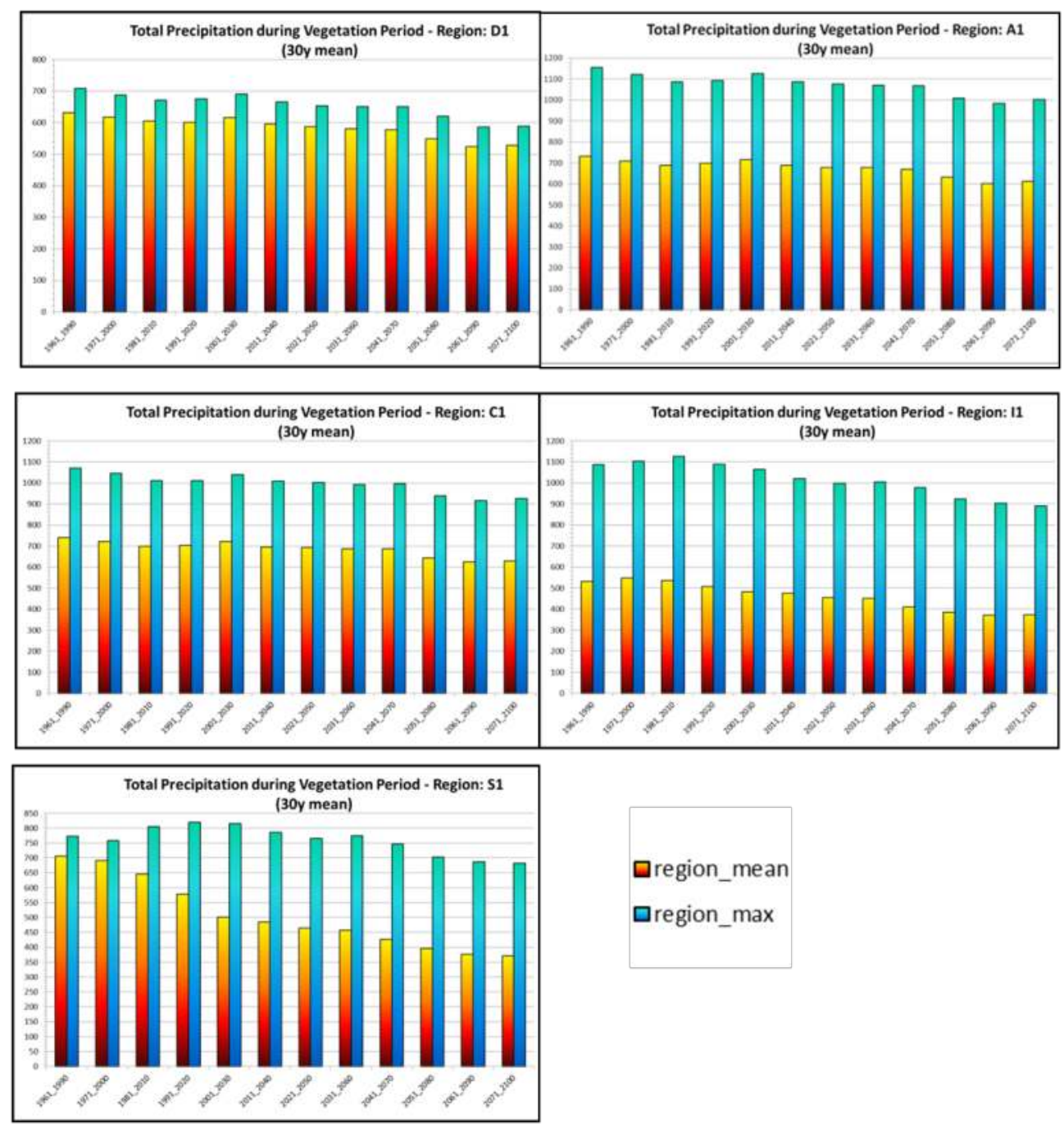

Figure 17. Mean total precipitation during the vegetation period from 1971-2000 to 2071/2100 for case study regions D1, A1, C1, 11 and S1 (Source: ECHAM5/CLM A1B Consortial run, 18x18km resolution, 1x1 km downscaling: WSL. Data compilation and analysis: AIT)

till 2100, the Swiss region (C1) starts from 48 (average) / 55 (max) dry days and will face an increase of app. 15 dry days till 2100. The Vorarlberg Region (A1) with alpine climate and some moderate influence of Lake Constance starts with 80 (average) / 90 (max) dry days and may expect another 20 dry days till 2100. In the small Slovenian region (S1) the number of dry days will increase from app. 120 by 10 to 20 days till 2100. The large Italian region (I1) shows the widest range because of the Alpine and the Mediterranean influences with hottest tempera- 

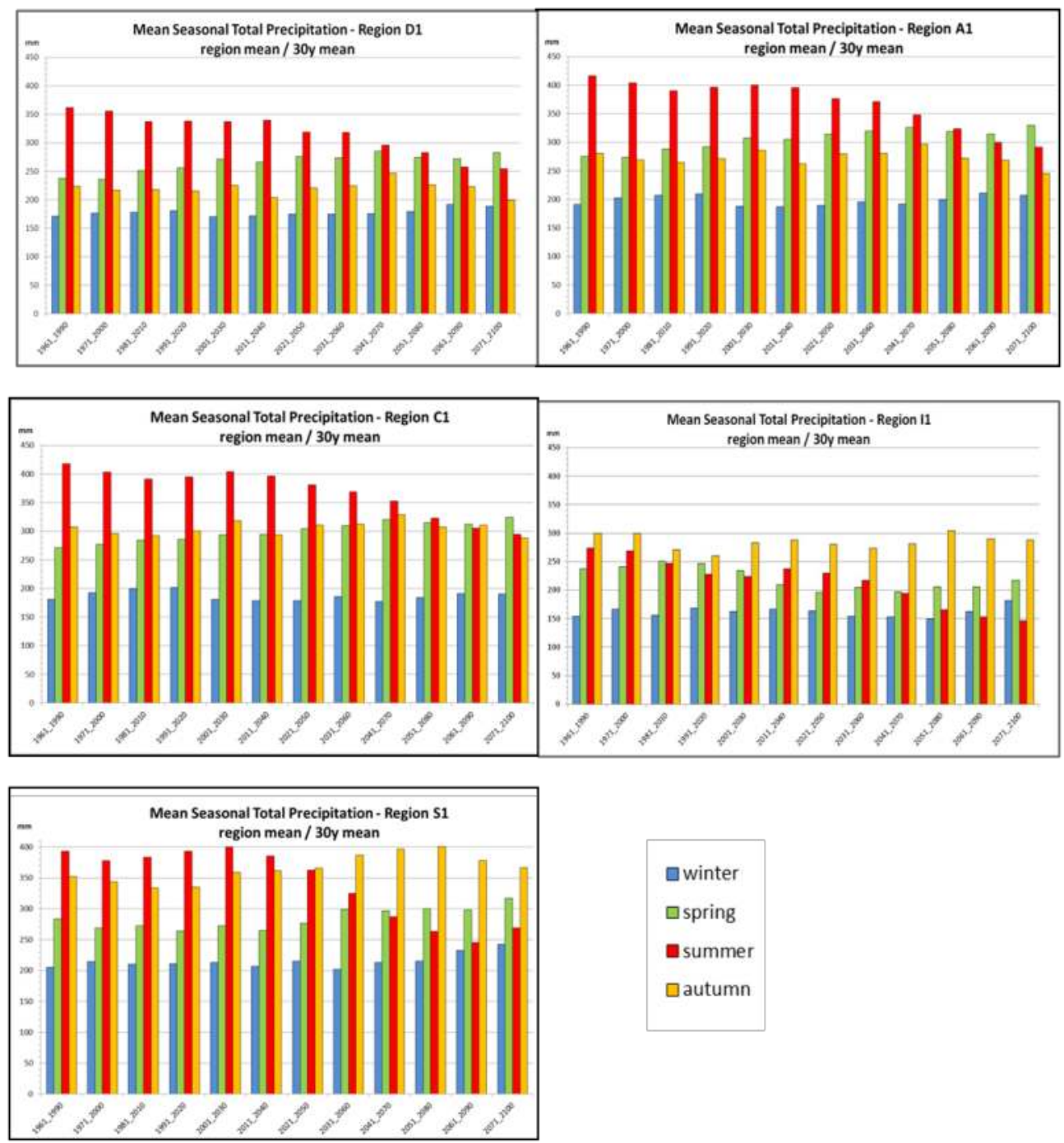

awinter
$\square$ spring
asummer
autumn

Figure 18. Mean seasonal total precipitation sums from 1971-2000 to 2071/2100 for case study regions D1, A1, C1, I1 and S1 (Source: ECHAM5/CLM A1B Consortial run, 18x18km resolution, 1x1 km downscaling: WSL. Data compilation and analysis: AIT)

tures in the Po Valley: 110 (average) and 135 (max.) dry days with an expected increase of 15 dry days.

The following table of diagrams (fig. 20) shows the evolution of the seasonal 30 year mean number of drought periods greater than 10 days for the selected case study regions. In general the number of more than 10-day dry periods for current climate accounts to 1-2 events per 

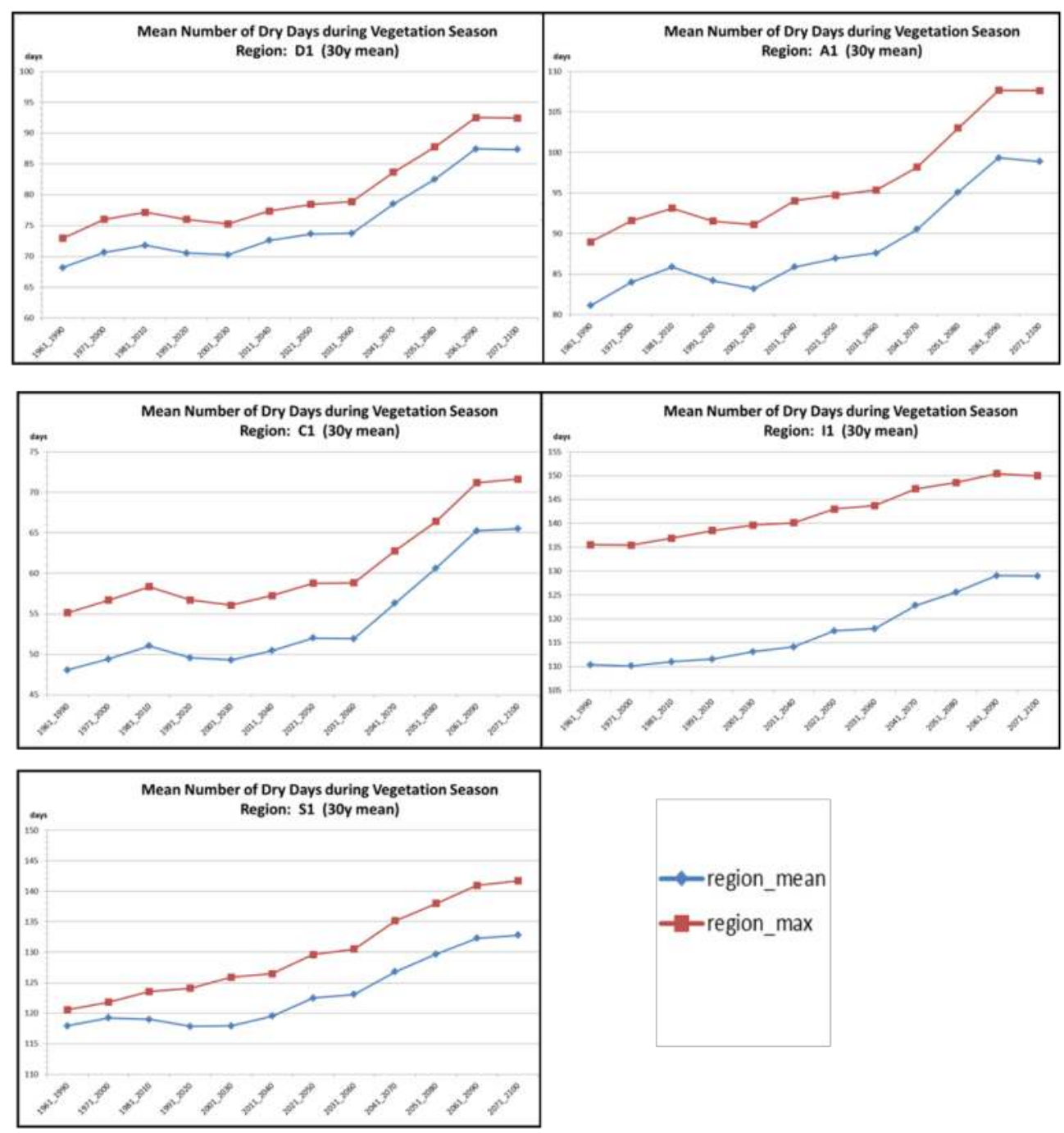

Figure 19. Mean number of dry days during vegetation season from 1971/2000 to 2071/2100 for case study regions D1, A1, C1, I1 and S1 (Source: ECHAM5/CLM A1B Consortial run, 18x18km resolution, 1x1 km downscaling: WSL. Data compilation and analysis: AIT)

season and is expected to grow by app. 1 event during summer months till the end of the century. All regions show a significant increase of such drought periods during summer. The northern regions (A1 and D1) show a rise up to nearly $200 \%$, the Slovenian region up to $90 \%$ and the Italian regions - due to higher occurrences at present - app. $40 \%$. At most locations there may be some reduction in spring, but overall changes during the other seasons except summer are not very significant. 


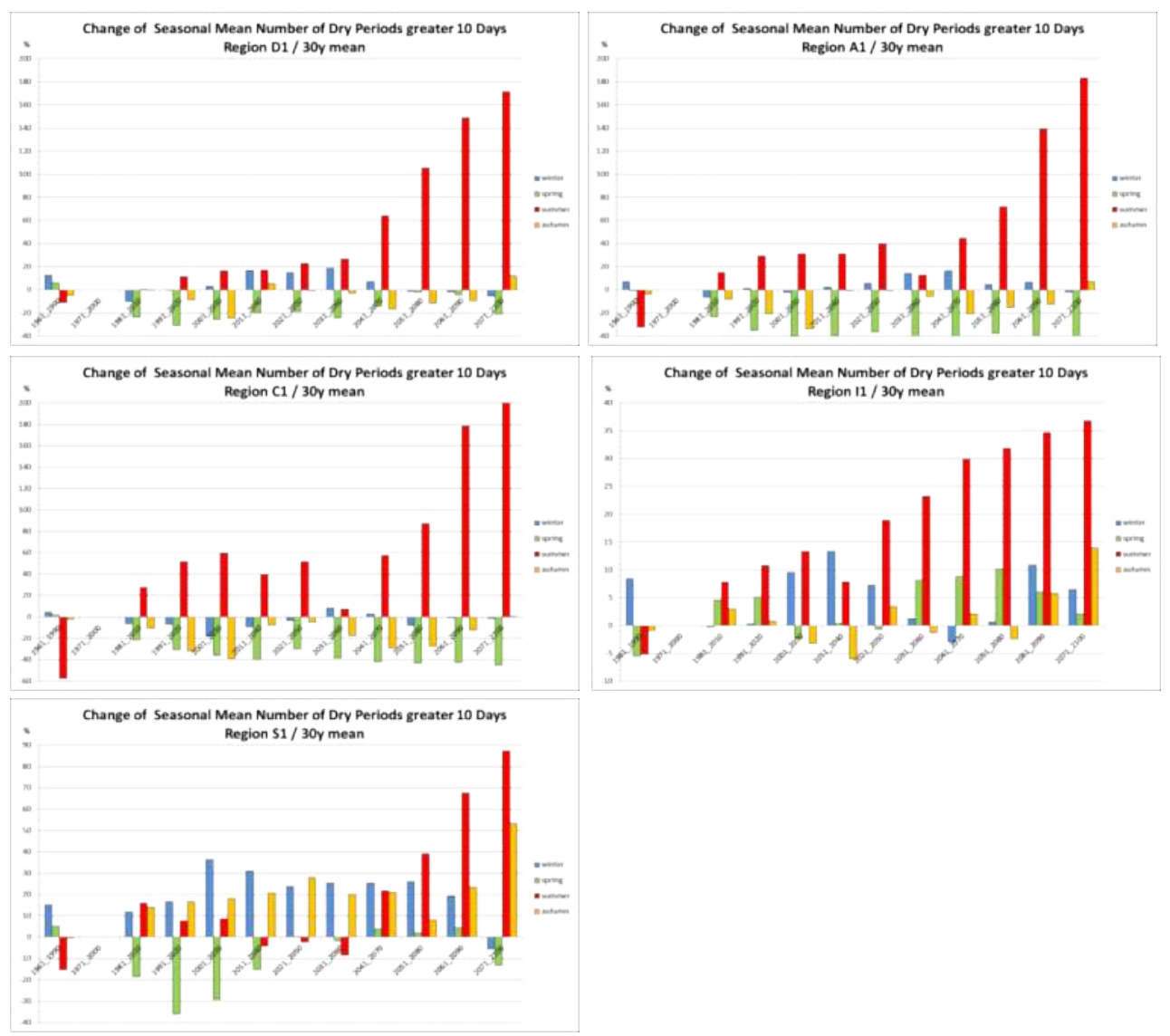

Figure 20. Relative change of mean number of dry periods greater than 10 days compared to period $1971 / 2000$ for case study regions D1, A1, C1, I1 and S1 (Source: ECHAM5/CLM A1B Consortial run, 18x18km resolution, 1x1km downscaling: WSL. Data compilation and analysis: AIT)

\section{General result discussion}

The Figures above let expect on the one hand a decrease of total precipitation within the vegetation period during the coming decades till 2100 and on the other hand a substantial increase of dry day periods - both aspects may lead to increasing drought stress in the particular forest areas in the greater alpine area.

- The tendency to significant lower rainfall in summer can be found in all areas. The decline of precipitation south of the Alpine main ridge (Northern Italy, Slovenia) is much stronger due to the Mediterranean influence. The applied climate scenario assumes a decline of 
summer precipitation up to $50 \%$. This surely will affect forests in southern regions and may lead to extended drought stress and fire hazard.

- A similar picture gives the comparison of the number of dry days in the future with the 30 year mean for 1971/2000 (Figure 20). The number of dry days north of the alpine main ridge is $1 / 3$ less than south of it. The increase of dry days is estimated to achieve 15 to 20 additional days, which is quite severe in the southern regions with numbers above 120 dry days for current climate. The number of dry day episodes as well as the length of the periods is expected to increase in all regions by 2 or 3 events per length class for the shorter episodes. The long periods (20 to 30 days) occur only in the southern regions and are also expected to increase.

Thus the combination of precipitation decrease, increase of the length of dry day periods as well as the increase of temperature may result in severe drought stress effects on the forest areas.

Investigations of forest growth and dendroecology compiled from tree ring chronologies have shown that differences between tree species to cope drought events in wide range occur. Over a longer period after an intense drought event ${ }^{14}$ Norway spruce tend to be more effected as common beech and Scots pine. Pedunculate and sessile oak species showed very little growth losses in the investigations by Beck [1].

In general the estimation of the local risks for forest and forest management needs local forest experts and stakeholders which are able to balance the different demands on forests to sustain in the future. The presented results of the single case study regions of the project MANFRED can be used as input for these analyses by local experts. The MANFRED project provides much more information than discussed within this book chapter. Detailed data have been provided to the stakeholder of the different case study regions and all MANFRED project partners.

\section{Uncertainty and spatial variability of regional climate projections}

Uncertainty in regional climate projections can be roughly divided into four components: (1) Natural variability ${ }^{15},(2)$ uncertainty in external forcing (mainly anthropogenic forcing like greenhouse gas emissions and land use change $)^{16}$, (3) uncertainty due to imperfect simulation of the climate system (model uncertainty $)^{17}$, and (4) downscaling uncertainty. Prein et al. ([15, 16]) analysed the relative contributions of natural variability, emission scenarios and models to total uncertainty over Europe. The uncertainty components for air temperature and precipi-

\footnotetext{
14 e.g. the drought of 2003 in middle Europe

15 The term natural variability refers to deterministic and random fluctuations in the climate system, that occur on various spatial and temporal scales,[3].

16 GHG emissions depend on many factors including growth of population and economy, energy prices and energy source selection, cultural and social interactions, technological development and land use, the latter serving either as GHG sink or as GHG emission accelerator. Since it is impossible to strictly predict the future development of these factors, the pathway of future emissions remains uncertain. The IPCC Special Report on Emission Scenarios (SRES) [14] provides different storylines of how the world might develop and the associated trajectory of future GHG emissions.
} 
tation over Europe due to internal variability, model formulation, and emission scenario assumptions until the mid and the end of the $21^{\text {st }}$ century are regarded in Prein's study, based on 23 different GCMs driving 84 simulations of the CMIP $3^{18}$ ensemble.

They found that uncertainty due to the formulation of the climate models describing atmospheric processes is largest for temperature as well as precipitation regime changes. The following Figure 21 presents a comparison of simulation results for seasonal change of temperature and precipitation in the south western part of the greater alpine Region (GAR) the region, where most of our case study regions are located.

Changes of precipitation amount are calculated relative with respect to 1961-1990. The black lines indicate the median changes, [5].

The cross in the diagrams marks the median of precipitation change (horizontal) and temperature change (vertical): The temperature change medians of the four seasons oscillate between 1.2 and $2{ }^{\circ} \mathrm{C}$ while the seasonal precipitation change medians shows rates of 0 to $7 \%$ of the particular precipitation total. The changes of all seasonal temperature means show the widest range between $+0.5^{\circ} \mathrm{C}$ and $3^{\circ} \mathrm{C}$ during summer. The ECHAM5-driven simulation marked with green dots show always the smallest temperature gain, while the HADCM3-based ${ }^{19}$ results marked with blue and purple dots show constantly the highest increase. For precipitation the single models show high deviations during the seasons, ranging from -20 to $+20 \%$. ECHAMbased models show declines in spring and summer, and (little) precipitation increase in autumn and winter, while the HADCM3-scenarios show no clear trend indicating some increase as well as some decrease during the seasons. These results give an idea of the uncertainty range which can be expected also for the model output applied in MANFRED.

But uncertainty shall not be mixed up with spatial variability unless the variability itself shows uncertainty: A rough exploration of the spatial variability - and the uncertainty - has been conducted in the project reclip:century carried out by AIT ([13], http://reclip.ait.ac.at/ reclip_century).

Besides uncertainty, there are also distinct location related differences between the regions, which are effects of terrain and position within the global atmospheric pressure and humidity motion patterns. Thus the simulations show a clear influence of the Alpine main ridge on the spatial distribution of climate change signals, with e.g. precipitation increase north of the Alps in spring, summer and autumn, and some decline in the southern and western parts. The temperature change pattern show rather an east-west- than a north-south-gradient. For Austria regional change trends for temperature and precipitation have been extracted from three regional climate simulation runs (based on 2 GHG scenarios and 3 RCM/GCM-combinations ${ }^{20}$ )

\footnotetext{
17 Uncertainties due to climate models arise from incomplete understanding and simplified formulation of climate processes in the models [19]. In order to quantify these uncertainties, ensembles of different or modified climate models are used.

18 Coupled Model Intercomparison Project Phase III, http://cmip-pcmdi.llnl.gov/, accessed 08.04.2013

19 "HadCM3 stands for the Hadley Centre Coupled Model version 3. It was developed in 1999 and was the first unified model climate configuration not to require flux adjustments (artificial adjustments applied to climate model simulations to prevent them drifting into unrealistic climate states)".http://www.metoffice.gov.uk/research/modelling-systems/ unified-model/climate-models/hadcm3, accessed 5 September 2012
} 
CCS 2-m Air Temp. \& Precip. Amount 1961-90/2021-50 region: GAR-Southwest, season: DJF

$$
+-\Pi \text { - }+\infty
$$

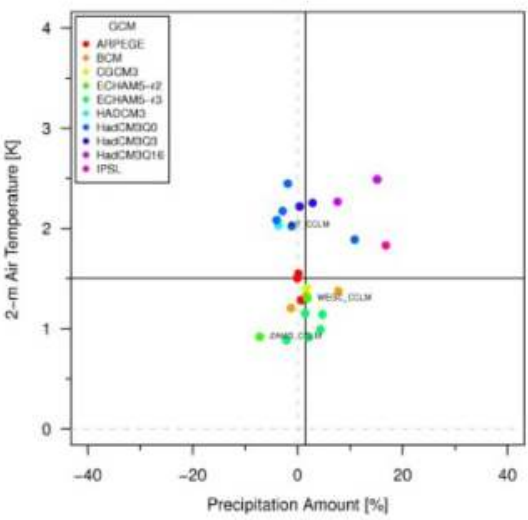

CCS 2-m Air Temp. \& Precip. Amount 1961-90/2021-50 region: GAR-Southwest, season: JJA

$$
\text { +.. } \square-\ldots+1
$$

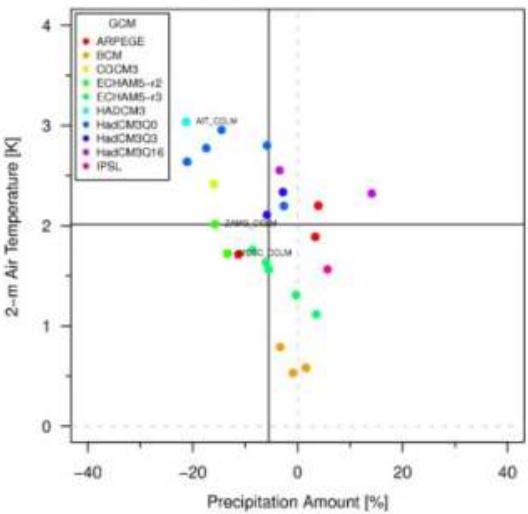

CCS 2-m Air Temp. \& Precip, Amount 1961-90/2021-50 region: GAR-Southwest, season: MAM
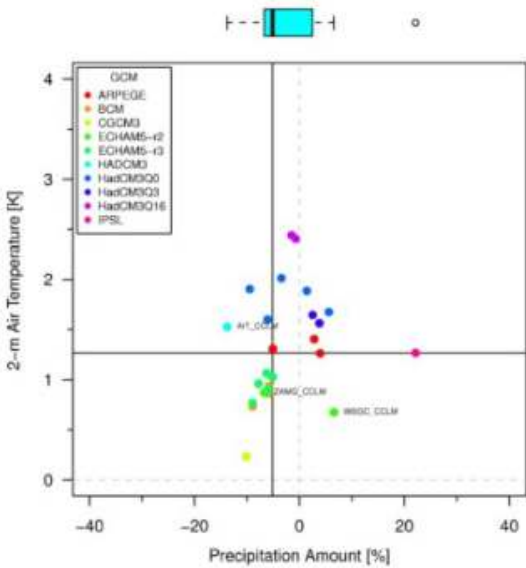

CCS 2-m Air Temp. \& Precip. Amount 1961-90/2021-50 region: GAR-Southwest, season: SON

$$
\text { - } \quad+\square \square \ldots+. . .+
$$

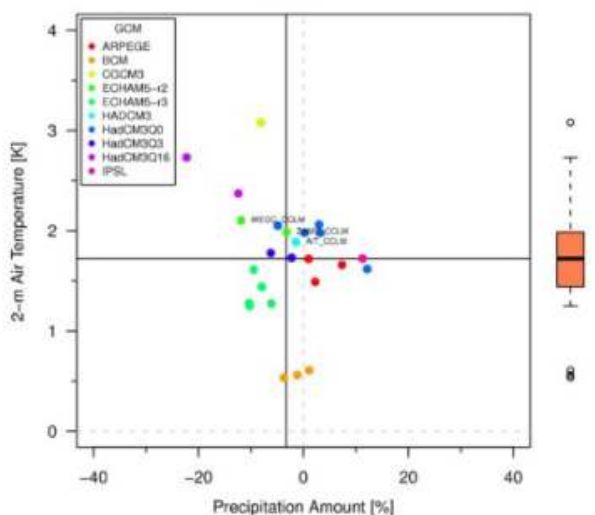

Figure 21. Scatter plots for the changes in 2-m air temperature and precipitation amount between 2021/2050 and 1961/1990 for GAR-South-west for 22 ENSEMBLES simulations (http://www.ensembles-eu.org) [10, 11].

20 The observed seasonal changes till 2050 as explored in these three reclip:century simulations are integrated in the diagrams in Fig. 21 and marked by names: AIT-CCLM is based on a A1B/HADCM3/CCLM combination, WEGC-CCLM is based on an A1B/ECHAM5/CCLM combination and ZAMG-CCLM is based on a B1/ECHAM5/CCLM model combination. 
for the four seasons and related to Austrian climate regions. The range of climate change signals within a region refers to uncertainty, the range of climate change signals between the regions refers to local effects of spatial variability ${ }^{21}$.

\begin{tabular}{lll}
\hline Winter: & & \\
\hline & temperature: +1.6 to $+2.2^{\circ} \mathrm{C}$, & prec.: +8 to $+13 \%$ increase \\
\hline more in $\mathrm{E}$ & less increase in the $\mathrm{S}$ and $\mathrm{W}$ \\
\hline temperature: +1.0 to $+1.2^{\circ} \mathrm{C}$. & prec.: constant to light decreases, \\
\hline more distinct in the $\mathrm{E}$ & \\
\hline temperature: +1.0 to $+2.5^{\circ} \mathrm{C}$, & prec.: little loss, \\
\hline scenarios disagree! & more distinct in the $\mathrm{S}$ \\
\hline Autumn: & temperature: +1.7 to $+2.3^{\circ} \mathrm{C}$, & prec.: little loss, \\
\hline W, S: higher increase, $\mathrm{N}:$ divergent & more distinct in $\mathrm{S}, \mathrm{SE}$ and eastern Alps
\end{tabular}

Such general location based variability/uncertainty in climate signal change can be expected for the entire Greater Alpine Region.

\section{Further research and conclusion}

The drought analysis within the MANFRED project where concentrated on the analysis of predicted input changes from precipitation and temperature. The local effects of changes in precipitation, drought length and frequencies or heat waves have to be estimated with local experts including local site conditions. The results show different manifestations of the assumed climate change scenario (A1B) within different areas, especially north or south of the alpine main ridge. It has to be noticed that the analysed climate change scenario is not an extreme scenario, thus the real changes in temperature and precipitation might lead to more severe hazards for forests in the future (see Figure 4 and 5). Above we briefly mentioned the uncertainties of climate change scenarios, which especially referring to precipitation are not neglectable, thus reducing this uncertainty should be one important research task for the future. Beyond this more ample spatial referenced information about site conditions as soil texture, surface runoff, evapotranspiration etc. would be very important to develop a closer understanding of the local hydrological conditions for the whole analysed Greater Alpine Region. A general increase in winter precipitation (mainly in northern and central Europe) and 
decreases in summer precipitation (mainly in central and southern Europe) can be found in different climate scenario simulation. Analysis of extreme events (as drought periods, length and frequencies) have more drastic consequences on tree growth than gradual changes in mean climate conditions [12]. In the future more advanced extreme event analyses have to be developed corresponding with reduced uncertainty in climate change scenarios.

\section{Author details}

Ernst Gebetsroither*, Johann Züger and Wolfgang Loibl

*Address all correspondence to: Ernst.Gebetsroither@ait.ac.at

AIT Austrian Institute of Technology GmbH, Foresight \& Policy Development Department, Vienna, Austria

\section{References}

[1] Beck, W. Auswirkungen von Trockenheit und Hitze auf den Waldzustand in Deutschland- waldwachstumskundliche Ergebnisse der Studie im Auftrag des BMELV: DVFFA- Sektion Ertragskunde, Jahrestagung 2010 http://www.nw-fva.de/ $\sim$ nagel/SektionErtragskunde/band2010/Tag2010_07.pdfaccessed on 6 September (2012).

[2] Déqué, M, et al. An intercomparison of regional climate simulations for Europe: assessing uncertainties in model projections, Clim. Change., 81, suppl. 1, DOIs10584-006-9228-x, (2007).

[3] Ghil, M. Natural Climate Variability in Encyclopedia of Global Environmental Change, The Earth System: Physical and Chemical Dimensions of Global Environmental Change. John Wiley \& Sons, Ltd: Chichester, (2002). , 1

[4] Granier, A, Reichstein, M, Bréda, N, Janssens, A, Falge, E, Ciais, P, Grünwald, T, Aubinet, M, Berbigier, P, Bernhofer, C, Buchmann, N, Facini, O, Grassi, G, Heinesch, B, Ilvesniemi, H, Keronen, P, Knohl, A, Köstner, B, Lagergren, F, Lindroth, A, Longdoz, B, Loustau, D, Mateus, J, Montagnani, L, Nys, C, Moors, E, Papale, D, Peiffer, M, Pilegaard, K, Pita, G, Pumpanen, J, Rambal, S, Rebmann, C, Rodrigues, A, Seufert, G, Tenhunen, J, \& Vesala, T. and Wang, Q: Evidence for soil water control on carbon and water dynamics in European forests during the extremely dry year: 2003. Agricultural and Forest Meteorology, (2007). , 143, 123-145.

[5] Heinrich, G, \& Gobiet, A. reclip:century Uncertainty Assessment. Report Part D: Wegener Center, 2011, Graz (http://reclip.ait.ac.at/reclip_century,accessed 28 September (2012). , 1 . 
[6] Hemery, G. E. Forest management and silvicultural responses to predicted climate change impacts on valuable broadleaved species. Short-Term Scientific Mission report for Working Group 1, COST Action E42, (2007). refs. www.ForestryHorizons.eu., 196.

[7] Hollweg, H, Böhm, D, Fast, U, Hennemuth, I, Keuler, B, Keup-thiel, K, Kysely, E, Kalvova, J, \& Kveton, J. V. Heat Waves in the South Moravian Region during the Period 1961-1995. Studia geoph. Et geod., (2000). , 44, 57-72.

[8] Keuler, K, Lautenschlager, M, Wunram, C, Keup-thiel, E, Schubert, M, Will, A, Rockel, B, \& Boehm, U. Climate Simulation with CLM, Scenario A1B run Data Stream 2: European region MPI-M/MaD. World Data Center for Climate, (2009). (1)

[9] Kysely, J. Mortality and displaced mortality during heat waves in the Czech Republic. Int. J. Biometeorol, (2004). , 49, 91-97.

[10] Lautenschlager, M, Legutke, S, Radtke, K, Rockel, B, Schubert, M, Will, A, Woldt, M, \& Wunram, C. Ensemble Simulations over Europe with the Regional Climate Model CLM forced with IPCC AR4 Global Scenarios. Model and Data group, Max Planck Institute for Meteorology, Hamburg, (2008). Technical Report 1619-2257(3), 150.

[11] Lautenschlager, M, Keuler, K, Wunram, C, Keup-thiel, E, Schubert, M, Will, A, Rockel, B, \& Boehm, U. Climate Simulation with CLM, Climate of the $20^{\text {th }}$ Century run Data Stream 2: European region MPI-M/MaD. World Data Center for Climate., (2009). doi:DOI:10.1594/WDCC/CLM_C20_1_D2.http://dx.doi.org/DOI:10.1594/ WDCC/CLM_C20_1_D2(1)

[12] Lindner, M, Garcia-gonzalo, J, \& Kolström, M. (2008). Impacts Of Climate Change On European Forests And Options For Adaptation." European Forest, 2008; http:// www.metla.eu/tapahtumat/2009/JFNW2009/Lindner.pdf.doi:DOI:10.1594/WDCC/ CLM_A1B_1_D2.http://dx.doi.org/DOI:10.1594/WDCC/CLM_A1B_1_D2, accessed 28 September 2012), 40ff.

[13] Loibl, W, Züger, J, \& Köstl, M. eclip:century 1. Report Part C: Climate Scenarios: Comparative Analysis, AIT, Vienna, 2011; (http://reclip.ait.ac.at/reclip_century, accessed 28 September (2012).

[14] Nakicenovic, N, Alcamo, J, Davis, G, De Vries, B, Fenhann, J, Gaffin, S, Gregory, K, Grübler, A, Jung, T. Y, \& Kram, T. La Rovere EL, Michaelis L, Mori S, Morita T, Pepper W, Pitcher H, Price L, Raihi K, Roehrl A, Rogner H-H, Sankovski A, Schlesinger M, Shukla P, Smith S, Swart R, van Rooijen S, Victor N, Dadi Z. IPCC Special Report on Emissions Scenarios. Cambridge University Press: Cambridge, United Kingdom and New York., 2000; http://www.ipcc.ch/pdf/special-reports/spm/sres-en.pdfaccessed 28 September (2012).

[15] Prein, A. Uncertainties in the driving data of regional climate models in the Alpine region. Wegener Center Scientific Report Wegener Center Verlag: Graz, Austria, (2009). (30-2009), 30-2009. 
[16] Prein, A. F, Gobiet, A, \& Truhetz, H. Analysis of uncertainty in large scale climate change projections over Europe Meteorol. Z., doi:(2011). , 20, 383-395.

[17] Roeckner, E, Bäuml, G, Bonaventura, L, Brokopf, R, Esch, M, Giorgetta, M, Hagemann, S, Kirchner, I, Kornblueh, L, Manzini, E, Rhodin, A, Schlese, U, Schulzweida, U, \& Tompkins, A. The atmospheric general circulation model ECHAM 5. PART I: Model description, (2003).

[18] Roeckner, E, Lautenschlager, M, \& Schneider, H. . IPCC-AR4 MPI-ECHAM5_T63L31 MPI-OM_GR1.5L40 SRESA1B run no.1: atmosphere 6 HOUR values MPImet/MaD Germany. World Data Center for Climate, 2006; DOI:10.1594/WDCC/EH5T63L31_OM-GR1.5L40_A1B_1_6H. http://dx.doi.org/10.1594/WDCC/EH5T63L31_OM-GR1.5L40_A1B_1_6H (accessed 28 September 2012)

[19] Stainforth, D. A, Allen, M. R, Tredger, E. R, \& Smith, L. A. Confidence, uncertainty and decision-support relevance in climate predictions. Phil. Trans. R. Soc, (2007). A 365: 2145-2161. DOI:rsta.2007.2074. 
